\title{
The controvertible role of kava (Piper methysticum G. Foster) an anxiolytic herb, on toxic hepatitis
}

\author{
Maria F. D. Amorim ${ }^{1 *}$, Margareth F. F. M. Diniz ${ }^{1}$, Maria S. T. Araújón , João C. L. R. Pita \\ Jadson G. Dantas 3 , Josué A. Ramalho ${ }^{3}$, Aline L. Xavier ${ }^{3}$, Thayse V. Palomaro, \\ Nelson L. B. Júnior ${ }^{3}$ \\ ${ }^{1}$ Laboratório de Toxicologia (LABETOX), Laboratório de Tecnologia Farmacêutica Prof. Delby Fernandes de \\ Medeiros, Universidade Federal da Paraíba, Campus Universitário, 58051-900, João Pessoa, PB, Brasil, \\ ${ }^{2}$ Serviço de Anatomia Patológica, Hospital Universitário Lauro Wanderley, Universidade Federal da Paraíba, \\ Campus Universitário, 58051-900, João Pessoa, PB, Brasil, \\ ${ }^{3}$ Curso de Farmácia, Departamento de Ciências Farmacêuticas, Universidade Federal da Paraíba, Campus \\ Universitário, 58051-900, João Pessoa, PB, Brasil
}

\begin{abstract}
RESUMO: “O papel controvertido da kava (Piper methysticum G. Foster) - Fitoterápico ansiolítico, na hepatite tóxica". Kava é um fitoterápico ansiolítico usado no tratamento da insônia e da ansiedade. Alguns casos de hepatotoxicidade induzida pela kava foram relatados na literatura, levando à proibição do seu uso em muitos países. Clinicamente, o espectro dessas alterações variou de elevações transitórias das enzimas hepáticas, até à falência hepática fulminante e morte. Em alguns casos, realizou-se transplante hepático. Este artigo revisa a literatura atual sobre a hepatite tóxica provavelmente relacionada à kava, discute os possíveis mecanismos responsáveis pela hepatotoxicidade potencialmente grave e descreve alguns aspectos que devem ser considerados quando eventos adversos hepáticos pareçam ser relacionados à administração dessa substância. Conclui-se que a possível toxicidade hepática pela kava ainda deve ser investigada e que algumas medidas antes e durante o seu uso são importantes, dada a possibilidade de disfunção hepática grave.
\end{abstract}

Unitermos: Piper methysticum, Piperaceae, kava, hepatite tóxica.

\begin{abstract}
Kava is an anxiolytic herbal medicine used in the treatment of sleep and anxiety disorders. Some cases of kava-induced hepatotoxicity have been reported in the literature leading to its banishment in most countries worldwide. Clinically, the spectrum ranged from transient elevations of liver enzyme levels to fulminant liver failure and death. Liver transplantation was performed in a few cases. This paper provides a review of the currently available literature on kava-related toxic hepatitis which may result from its use, discusses the possible mechanisms for the potentially severe hepatotoxicity and describes some features which must be considered when adverse liver effects seem to be associated to kava administration. In conclusion, the incidence of kava toxicity on the liver remains to be investigated; however, some concerns before or during kava use are important, due to the possibility of severe liver dysfunction.
\end{abstract}

Keywords: Piper methysticum, Piperaceae, kava, hepatitis, toxic.

\section{INTRODUCTION}

Herbal medicines are being used by an increasing number of patients who typically do not advise their clinicians of their concomitant use. Natural products in folk medicine have been used for centuries (Cordeiro et al., 2005), and they are generally regarded by the public as harmless remedies (Miller, 1998; Stickel et al., 2005).

Nevertheless, hepatotoxicity could happen during some treatments with herbal remedies, and several of them have produced hepatitis in humans (Lekehal et al., 1996). Therefore, potential hepatotoxicity of herbal products should not be underestimated (Dufour; St-
Pierre, 2002). When a patient presents with unexplained hepatic abnormalities, it may be worthwhile to consider non-orthodox self-treatment with herbal remedy as a potential cause (Pauwels et al., 1992).

Kava or kava-kava (Piper methysticum G. Foster), an herbal product for sleep and anxiety disorders that contains kavalactones, is available over-the-counter in many countries (Russmann et al., 2001). Recently, several reports about kava hepatotoxicity have been published, including fulminant liver failure, leading to liver transplantation (Kraft et al., 2001; Russmann et al., 2001; Gow et al., 2003; Humberston et al., 2003; Stickel et al., 2005).

The concern over the possible hepatoxicity of 
kava has led several regulatory agencies in countries such as Germany, Switzerland, France, Canada, the United Kingdom, as well as the United States, warning consumers about the safety or potential risks of kava use, or removing kava-containing products from the marketplace (Food and Drug Administration, 2002; MCA, 2005; AFSSAPS, 2006). The Brazilian regulatory agency Agência Nacional de Vigilância Sanitária (ANVISA) has determined (RE 356, February 28, 2002) that all products with kava must be registered and have a red label with the inscription "Dispensed with a medical prescription" (ANVISA, 2006).

This paper provides a review of the current literature on toxic hepatitis probably related to kava use and the questions about this herbal remedy. We reviewed data published between August 1966 and until June 2006 on databases MEDLINE / LILACS, PubMed (http://www.ncbi.nlm.nih.gov/entrez/query. fcgi?DB=pubmed).

The search terms were "kava", "Piper methysticum", "hepatitis, toxic". We found 774 references and 65 of them were selected between full text articles, abstracts and correspondences in English, Portuguese, Spanish and French.

\section{History, therapeutic use, pharmacology and side} effects of kava (Piper methysticum)

Kava-kava (Piper methysticum) is a member of the pepper family (Piperaceae group) found in the South Pacific Islands, with medicinal use (Russmann et al., 2001). The first description of the plant was made by Swedish botanists during the first expedition of Captain James Cook in the South Pacific area in 1768-1771 (Bilia et al., 2004).

This plant has been used for centuries as a highly revered ceremonial and medicinal drink producing mild narcotic effects (Yamada et al., 2003). Folk medicine suggests that kava also may treat sleeplessness and tension/anxiety, headaches, colds, rheumatism, menopausal symptoms, venereal diseases, menstrual and genitourinary tract problems (Bilia et al., 2004).

In the Western world, kava is commercially available as an herbal remedy and has been used predominantly to treat anxiety. Many studies suggest kava may be as effective as benzodiazepines (Andreatini et al., 2001; Bilia et al., 2002; Lehrl, 2004). The significant anxiolytic effect is assessed by the Hamilton Rating Scale for Anxiety, with good tolerability (Pittler; Ernst, 2000). It is a well-established hypnotic drug, with a rapid onset of effect and adequate action period (Wheatley, 2005).

Kavalactones (or kavapyrones) are considered to be the active constituents of kava-kava responsible for the pharmacological activity in humans and animals (Pittler; Ernst, 2000; Siméoni; Lebot, 2002; Pittler; Ernst, 2003). There are 18 different kavalactones which are usually metabolized in the liver by the cytochrome P450 system (CYP450). The major are methysticin, dihydromethysticin, kavain, dihydrokavain, demethoxyyangonin, and yangonin, which account for $96 \%$ of the organic extract (Lebot; Levesque, 1989). Dihydrokavain may be necessary and sufficient in mediating the anxiolytic properties of $P$. methysticum extract (Feltenstein et al., 2003).

There is also evidence for serotonergic and calcium antagonistic potencies of kavain, but the cellular actions of this kavapyrone appear heterogeneous, all of them counter excitation (Grunze; Walder, 1999). Sleep disturbances associated with non-psychotic anxiety disorders can be effectively and safely treated with kava extract (Lehrl, 2004), nevertheless authors suggests that it might prove to be a useful treatment for epilepsies, bipolar disorders, depression and anxiety, all conditions characterized by increased cellular excitability (Grunze; Walder, 1999). Methysticin and kavain inhibit voltageoperated sodium channels in rat neurons (Magura et al., 1997).

The mechanisms to explain the anxiolytic action of kava probably involve a reduction in the excitability of the limbic system, particularly the amygdala complex.

Pharmacological properties of Piper methysticum include blockade of voltage-gated sodium ion channel; enhanced ligand binding to gamma-aminobutyric acid (GABA) type A receptors (kavapyrones are GABA receptors agonists through the inhibition of activating neurons in the reticular formation and the limbic system); diminished excitatory neurotransmitter release due to calcium ion channel blockade; reduced neuronal reuptake of noradrenaline; reversible inhibition of monoamine oxidase $B$ and suppression of the synthesis of the eicosanoid thromboxane $\mathrm{A} 2$, an antagonist of GABA A receptor function (Clouatre, 2004). Although it is suggested that kava should be a dopamine antagonist, available data are not conclusive (Stevinson, 2002).

Before 1998, extracts of kava were considered to be very safe alternatives to anxiolytic drugs (Clouatre, 2004). Adverse effects imputed to kava were generally considered to be mild or negligible. It may cause dermatological side-effects (Ernst, 2000); oral (Abebe, 2002) and neurological manifestations (Spinella, 2001; Meseguer et al., 2002; Sibon, 2002). Myoglobinuria has also been reported after ingestion of an herbal combination product containing kava (Donadio et al., 2000).

However, in the past few years, severe side effects, including liver damage resulting in a few cases of mortality, have been reported. Nowadays, a total of 78 cases of hepatotoxicity reputedly linked to kava ingestion are available from various databases (Clouatre, 2004; Côté et al., 2004). 


\section{Toxic hepatitis induced by kava}

Kava use is associated with liver damage and the potentially severe hepatotoxicity of kava is emphasized by Stickel et al. (2003). Using a clinical diagnostic scale established for adverse hepatic drug reactions, they analyzed 29 cases of hepatitis along with kava ingestion which occurred between 1990 and 2002, in addition to the seven already published case reports suggesting the development of hepatitis after the intake of kava. Lack of dose-dependence of kava-associated adverse hepatic events was evident in this report.

Nine patients developed fulminant liver failure, of which eight patients underwent liver transplantation. Three patients died, two following unsuccessful liver transplantation. In all other patients, a complete recovery was noticed after the withdrawal of kava. Hepatic necrosis or cholestatic hepatitis was noticed with both alcoholic and acetonic kava extracts.

Liver biopsy showed infiltrated portal tracts, bridging necroses, destruction of interlobular bile ducts, and canalicular cholestasis. A mixed cellular infiltrate (lymphocytes, eosinophil granulocytes and activated macrophages) involving interlobular bile ducts was a histopathologic finding (Russman et al., 2001). Marked eosinophilic infiltrated is showed in some cases (Stickel et al., 2003).

Recently, Musch et al. (2006) reported an acute hepatitis in a previous healthy 48 -year-old female, with histological characteristics of a toxic origin, classified as induced immunologic idiosyncratic hepatitis. She was taking simultaneously kava and St John's Wort, an inducer of CYP450 3A enzymes, which possibly potentiated the toxicity of kavapyrones.

Kava has hepatotoxic effects (De Smet, 2002), but the precise mechanism or mechanisms through which kava might induce liver damage is unknown. Whether kava is more hepatotoxic than conventional anxiolytic drugs is also unclear (Ernst, 2002).

Drugs are metabolized by a variety of processes involving oxidation, reduction and hidrolysis (phase I reactions) or glucuronidation, sulfation, acetylation, and methylation (phase II reactions) (Wilkinson, 2005). The pathogenesis of drug or toxin-induced liver injury usually involves the participation of toxic metabolites that either elicit an immune response or directly affect the biochemistry of the cell (Kaplowitz, 2002).

The best understood example of this process is acetaminophen intoxication. Safe in recommended therapeutic doses, large amounts of acetaminophen cause cellular necrosis, caused by a highly reactive metabolic product, N-acetiyl-benzoquinone-imide (NAPQI) (Maddrey, 2005). Cell death is the crucial event leading to the clinical manifestations of druginduced hepatotoxicity and the liver is usually the target of the immune system, but some drugs produce metabolites that also cause cell death independent of the extrinsic immune system (Kaplowitz, 2002). Pathophysiologically, both immunoallergic and idiosyncratic factors may be responsible. It is suggested that, in many cases, an individual metabolic idiosyncrasy must be considered (Stickel et al., 2005).

On the other hand, differences in drug response among patients are common. In druginduced hepatotoxicity, it is likely that the individual risk is determined by various combinations of the environmental and genetic variations in multiple factors (Kaplowitz, 2002). Genetic predisposition may be a risk factor for developing kava-related liver disease. In fact, toxic hepatitis in poor-metabolizer phenotype of cytochrome P450 2D6 are reported by Russmann et al. (2001).

\section{Possible mechanisms for kavalactones hepatotoxicity}

Whether kava or its constituents are hepatotoxic, where does liver toxicity come from? Three possible mechanisms for kavalactones hepatotoxicity are known: inhibition of cytochrome P450 (CYP 450), reduction in liver glutathione (GSH) content and, more remotely, inhibition of cyclooxygenase enzyme (COX) activity (Johnson et al., 2003; Whitton et al., 2003; Clouatre, 2004).

Drug interactions can raise the possibility of adverse effects (Wilkinson, 2005). Interactions between herbal and conventional drugs undoubtedly do occur and may put individuals at risk to develop adverse reactions (Fugh-Berman; Ernst, 2001; Côté et al., 2004). Many of these drug interactions are a result of inhibition or induction of cytochrome P450 enzymes, which are responsible for the metabolism of many drugs (Wilkinson, 2005). Kava has great potential for adverse effects, due the inhibition of several of these enzymes, resulting in pharmacokinetic interaction (Mathews et al., 2002).

In fact, whole kava extract decreases activities of CYP1A2, 2C9, 2C19, 2D6, 3A4 and 4 A9/11 in human liver microsomes. Kavain did not inhibit these enzymes, but desmethoxyyangonin, methysticin and dihydromethysticin inhibit CYP2C9; dihydromethysticin inhibit CYP2C19; methysticin inhibit CYP2D6; desmethoxyyangonin, methysticin and dihydromethysticin inhibit CYP3A4 (Mathews et al., 2002).

Certain individuals might be especially susceptible to kava-induced hepatotoxicity. A possible mechanism of kava-induced hepatotoxicity is suggested for cases in which the detoxification pathways for kavapyrones metabolites are modified. The formation of electrophilic quinoid metabolites (quinones) by hepatic microsomes in vitro suggests that they might contribute to liver injury, when the detoxification pathways become altered by a drug interaction, by a genetic difference in 
enzyme expression or if conjugation pathways become saturated (Johnson et al., 2003).

\section{Controversies about kava-related toxic hepatitis}

Despite these several theories as to the mechanism of kava hepatotoxicity, there is still no satisfactory answer. Some authors consider that on closer inspection, the majority of the case reports are probably not connected to kava intake (Denham et al., 2002; Anke; Ramzan, 2004).

The current discussion of potential deleterious effects of kava on liver calls for a closer look at the available data of the observed adverse effects connected to its intake.

Attribution of liver injury to a specific drug in a patient may be difficult, because the manifestations are sometimes similar to acute viral hepatitis (nausea, vomiting, jaundice, increased aminotransferases levels). There is no gold standard for the diagnosis in druginduced liver disease but clinical scales for causality assessment may be applied, facilitating the interpretation of findings (Naranjo at al., 1981; Kaplowitz, 2001). However, its true incidence is difficult to determine, and it is sometimes underestimated (Ernst; Pittler, 2003; Navarro; Senior, 2006). Therefore, extensive research for others causes of liver disease must be performed (Teschke et al., 2003).

In the spectrum of hepatic manifestations of drug-induced liver disease, the most frequent is acute hepatitis, with hepatocellular necrosis or cholestasis (or mixed hepatitis), ranging from minimal or moderate biochemical alterations to acute liver failure and death; chronic manifestations are less common (Maddrey, 2003). Eventually, AST and ALT levels could reach 30 times higher the upper normal limit, without symptoms or signs, in previously healthy patients (Amorim et al., 2005). Toxic effects of intentional overdose of acetaminophen may show extremely high aminotransferase levels (Lee, 2003).

There is no evidence for serious liver damage in kava-using populations in Pacific Island societies or in Indigenous Australians who have used moderate levels of consumption of aqueous kava extracts. Changes in liver function tests as high levels of liver enzymes gamma-glutamyl transferase (GGT) and alkaline phosphatase (ALP) appear to be reversible after 1 to 2 weeks abstinence from kava (Clough et al., 2003).

Russmann et al. (2003) also consider that the increased activity of GGT in heavy kava consumers in New Caledonia, in the presence of normal or minimally elevated transaminases is probably not a sign of liver injury, but rather reflects an induction of CYP450 enzymes.

In a background data on a total of 76 case reports of kava hepatotoxicity dating from 1990 to 2002, Schmidt (2006) suggested a possible or probable connection to kava in only one case, and considered that the risk of adverse liver effects seems to be very low. In rats, aqueous kava extracts do not affect liver function tests, nor malondialdehyde formation, which reflects the lipid peroxidation (Singh; Devkota, 2003).

\section{DISCUSSION}

Kava is cited among liver injury inducing drugs (Stickel et al., 2003), with predominantly hepatocellular pattern (Navarro; Senior, 2006). Even authors who consider hepatotoxicity in the course of kava use a rare adverse event, suggest safety recommendations and recognize the possibility of hepatotoxic effects (Teschke, 2003).

Kava has been shown to cause a decrease of glutathione in the liver (Clouatre, 2004). Hepatic GSH deficiency can disturb the physiological balance between apoptosis and necrosis, inflammation and proliferation and predisposes cells to oxidative injury. Liver toxicity of xenobiotics is greatly enhanced under this condition (Hentze et al., 2000). Glutathione plays an essential role in the phase II conversion of lactones into excretable waste products. Consequently, on glutathione depletion, increased side effects may occur (Whitton et al., 2003). Intracellular glutathione depletion by chronic and excessive ingestion of alcohol may also results in acetaminophen poisoning (Maddrey, 2005).

Kavalactones inhibit cyclooxygenase enzymes (COX-1 and COX-2) and this inhibition has been linked in other therapeutic drugs to hepatotoxicity, which is a common finding with drugs with this property and contribute to the risk of drug-induced liver disease (Clouatre, 2004).

Interactions between other drugs and herbal remedies is a very important question (Blendis, 2005), because kava is often consumed in combination with other pharmaceuticals metabolized by CYP3A4. In several cases reports, other medications with hepatotoxic potencial were being taken concurrently with kava by the patients (Stevinson, 2002; Cordeiro et al., 2005), raising the risk of toxic hepatitis.

The different methods of extraction of kavalactones from the roots may explain the toxicity of Western products compared with the safe use of the traditional beverage (Whitton et al., 2003). Once there are disparities between caplets and kava root extracts prepared using methanol, ethanol or acetone, the differences in the ratio of the kavalactones imply possible variations in biological activity and the hepatotoxicity could be the result of CYP450 inhibition, more pronounced for commercial preparations (Côté et al., 2004).

Herbal preparations are frequently contaminated with heavy metals, micro-organisms, toxic substances and adulterated with synthetic drugs (Bogusz et al., 2002). Alkaloid contamination may play a key role in

Rev. Bras. Farmacogn. Braz J. Pharmacogn 17(3): Jul./Set. 2007 
the liver toxicity associated with kava. Tests in vitro with exposure of human hepatoma cells (HepG2), to pipermethystine (a major kava alkaloid), suggest that it is, rather than kavalactones, capable of causing cell death, probably in part by disrupting mitochondrial function. Pipermethystine significantly decreased cellular ATP levels, mitochondrial membrane potential, and induced apoptosis as measured by the release of caspase- 3 after 24 h of treatment (Nerurkar et al., 2004).

Interaction between kava and ethanol is possible, and has important clinical consequences, such as the increased central nervous system depression. Whether this combination leads to liver damage are conflicting finds. In mice, ethanol increases the toxicity of kava, and in a community in Australia, non heavy alcohol users showed GGT and ALP levels higher than nonusers (Clough et al., 2003).

Authors suggest avoiding the concomitant use of alcohol and kava extracts, due to the changes in hepatic elimination of drugs that occur in alcohol addicts (Stevinson, 2002; Schmidt, 2006).

Although some investigators support that it is highly suggestive that kava itself produces toxicity, all these features described above must be considered because they are important to understanding what is going on with the patient taking kava, when liver disease appears.

\section{CONCLUSION}

Based on data found in the literature, we conclude that the incidence of kava toxicity on the liver remains to be investigated. In countries where kava products are available, clinicians, practicing physicians and clinical pharmacists must be aware of the toxic potential of this herbal sedative.

They should ask all patients about this use and always inquire about their intake in cases of unexplained liver injury. Previous hepatic impairment should be considered a contraindication for prescription.

Drug interactions can raise the possibility of adverse effects and drug metabolism may vary markedly among patients. Therefore, special care must be taken in cases of concomitant administration and these patients should be routinely and individually monitored.

Because of the possibility of kava-induced hepatotoxicity, a work-up for alternative causes of liver disease occurring during kava use is needed. Multiple factors may contribute to hepatic failure, which could become a life-threatening condition, even fatal.

\section{REFERENCES}

Abebe W 2002. Herbal medication: potential for adverse interactions with analgesic drugs. J Clin Pharm Ther 27: 391-401

AFSSAPS 2006. Agence Française de Securité Sanitaire des
Produits de Santé. Accessed June 20, 2006, at http:// agmed.sante.gouv.fr/htm/alertes/filalert/deciskav. $p d f$.

Amorim MFD, Amorim WPD, Duques P, Amorim PD, Vasconcelos JR 2005. Flutamide-induced hepatotoxicity during treatment of acne - A case report. An Bras Dermatol 80: 381-384.

Andreatini R, Boerngen-Lacerda R, Filho DZ 2001. Pharmacological treatment of generalized anxiety disorder: future perspectives. Rev Bras Psiquiatr 23: 233-242.

Anke J, Ramzan I 2004. Kava hepatotoxicity: Are we any closer to the truth? Planta Med 70: 193-196.

ANVISA 2006. Agência Nacional de Vigilância Sanitária Brasil (Legislação - Resoluções). Accessed Mai 4, 2006, at http://anvisa.gov.br.

Bilia AR, Gallori S, Vincieri FF 2002. Kava-kava and anxiety: growing knowledge about the efficacy and safety. Life Sci 70: 2581-2597.

Bilia AR, Scalise L, Bergonzi MC, Vincieri FF 2004. Analisis of kavalactones from Piper methysticum. $J$ Chromatogr B 812: 203-204.

Blendis L 2005. Chaos in hepatology: do we know what our patients are taking?. Gastroenterol 128: 240.

Bogusz MJ, Al Tufail M, Hassan H 2002. How natural are "natural herbal remedies"? A Saudi perspective. Adverse Drug React Toxicol Rev 21: 219-229.

Clouatre DL 2004. Kava kava: examining new reports of toxicity. Toxicol Lett 150: 85-96.

Clough AR, Bailie RS, Currie B 2003. Liver function test abnormalities in users of aqueous kava extracts. $J$ Toxicol-Clin Toxic 41: 821-829.

Cordeiro CHG, Chung MC, Sacramento LVS 2005. Interações medicamentosas de fitoterápicos e fármacos: Hypericum perforatum e Piper methysticum. Rev Bras Farmacogn 13: 272-278.

Côté CS, Kor C, Cohen J, Auclari K 2004. Composition and biological activity of traditional and commercial kava extracts. Biol Biophy Res Comm 322: 147-152.

De Smet PAGM 2002. Drug Therapy: herbal remedies. N Engl J Med 347: 2046-2056.

Denham A, McIntyre M, Whitehouse J 2002. Kava - the unfolding story: report on a work-in-progress. $J$ Altern Complem Med 8: 237-263.

Donadio V, Bonsi P, Zele I, Monari L, Liguori R, Vetrugno R, Albani F, Montagna P 2000. Myoglobinuria after ingestion of extracts of guarana, Ginkgo biloba and kava. Neurol Sci 21: 124

Dufour JF, St-Pierre MV 2002. Phytotherapeutic drugs in gastroenterology and hepatology. Ther Umsch 59: 313-316.

Ernst E 2000. Adverse effects of herbal drugs in dermatology. Brit J Dermatol 43: 923.

Ernst E 2002. Safety concerns about kava. Lancet 359: 1865.

Ernst E, Pittler MH 2003. Systematic review: hepatotoxic events associated with herbal medicinal products. Alim Pharm Ther 18: 451-471.

Feltenstein MW, Lambdin LC, Ganzera M, Ranjith H, Dharmaratne W, Nanayakkara NP, Khan IA, Sufka KJ 2003. Anxiolytic properties of Piper methysticum extract samples and fractions in the chick socialseparation-stress procedure. Phytother Res 17: 210216. 
Food and Drug Administration (FDA) 2002. Kava-containing dietary supplements may be associated with severe liver injury. Center for Food Safety and Applied Nutrition, U. S. Food and Drug Administration, Dietary Supplements.

Fugh-Berman A, Ernst E 2001. Herb-drug interactions: Review and assessment of report reliability. Brit $J$ Clin Pharmacol 52: 587-595.

Gow PJ, Connelly NJ, Hill RL, Crowley P, Angus PW 2003. Fatal fulminant hepatic failure induced by a natural therapy containing kava. Med J Aust 178: 442-443.

Grunze H, Walder J 1999. Kawain limits excitation in CA 1 pyramidal neurons of rats by modulating ionic currents and attenuating excitatory synaptic transmission. Hum Psychopharmacol Clin Exp 14: 63-66.

Hentze H, Gantner F, Kolb SA, Wendel A 2000. Depletion of hepatic glutathione prevents death receptordependent apoptotic and necrotic liver injury in mice. Am J Path 156: 2045-2056.

Humberston CL, Akhtar J, Krenzelok EP 2003. Acute hepatitis induced by kava kava. J Toxicol-Clin Toxic 41: 109113.

Johnson BM, Qiu HX, Zhang S, Zhang F, Burdette JE, Yu L, Boltom JL, Breemen RB 2003. Identification of novel electrophilic metabolites of Piper methysticum Forst (Kava). Chem Res Toxicol 16: 733-740.

Kaplowitz N 2001. Causality assessment versus guilt-byassociation in drug hepatotoxicity. Hepatology 33: 308-310.

Kaplowitz N 2002. Biochemical and cellular mechanisms of toxic liver injury. Semin Liver Dis 22: 137-144.

Kraft M, Spahn TW, Menzel J, Senninger N, Dietl KH, Herbst H, Domschke W, Lerch MM 2001. Fulminant liver failure after administration of the herbal antidepressant Kava-Kava. Dtsch Med Wochenschr 126: $970-972$.

Lebot V, Levesque J 1989. The origin and distribution of kava (Piper methysticum Frost. f. and Piper wichmanii C. DC., Piperaceae) a phytochemical approach. Allertonia 5: 223-281.

Lee WM 2003. Drug-induced hepatotoxicity. $N$ Engl J Med 349: 474-485.

Lehrl S 2004. Clinical efficacy of kava extract WSR 1490 in sleep disturbances associated with anxiety disorders. Results of a multicenter, randomized, placebocontrolled, double-blind clinical trial. $J$ Affect Disorders 78: 101-110.

Lekehal M, Pessayre D, Lereau JM, Moulis C, Fouraste I, Fau D 1996. Hepatotoxicity of the herbal medicine germander: metabolic activation of its furano diterpenoids by cytochrome P450 3A Depletes cytoskeleton-associated protein thiols and forms plasma membrane blebs in rat hepatocytes. Hepatology 24: 212-2188.

Maddrey WC 2003. Clinicophathological patterns of druginduced liver disease. In: Kaplowitz N, Deleve LD. Drug induced Liver Disease. New York: Marcel Dekker, Inc. $724 \mathrm{p}$.

Maddrey WC 2005. Drug-induced hepatotoxicity. J Clin
Gastroenterol 39(S2): 83-89.

Magura EI, Kopanitsa MV, Gleitz J, Peters T, Krishtal OA 1997. Kava extract ingredients, $(+)$-methysticin and $( \pm)$-kavain inhibit voltage-operated $\mathrm{Na}^{+}$-channels in rat CA1 hippocampal neurons. Neuroscience 81: 345-351.

Mathews JM, Etheridge AS, Black SR 2002. Inhibition of human cytochrome P450 activities by kava extract and kavalactones. Drug Metab Dispos 30: 11531157.

MCA 2005. Medicines Control Agency. Investigation of Kava Kava Leads to Ban Following Voluntary Withdrawal. December 20, 2002. Accessed October 12, 2005, at http://www.mca.gov.uk/whatsnew/pressreleases/ Kava211202.pdf.

Meseguer E, Taboada R, Sánchez V, Mena MA, Campos V, Yébenes JG 2002. Life-threatening parkinsonism induced by kava-kava. Mov Disorders 17: 195-196.

Miller LG 1998. Herbal medicinals: selected clinical considerations focusing on known or potential drugherb interactions. Arch Intern Med 158: 2200-2211.

Musch E, Chrissafidou A, Malek M 2006. Acute hepatitis due to kava-kava and St John's Wort: an immunemediated mechanism? Dtsch Med Wochenschr 131:1214-1217.

Naranjo CA, Busto U, Sellers EM, Sandor P, Ruiz I, Roberts EA, Janecek E, Domecq C, Greenblatt DJ 1981. A method for estimating the probability of adverse drug reactions. Clin Pharmacol Ther 30: 239-245.

Navarro VJ, Senior JR 2006. Drug-related Hepatotoxicity. $N$ Engl J Med 354: 731-739.

Nerurkar PV, Dragull K, Tang CS 2004. In vitro toxicity of kava alkaloid, pipermethystine, in HepG2 cells compared to kavalactones. Toxicol Sci 79: 106-111.

Pauwels A, Thierman-Duffaud D, Azanowsky JM, Loiseau D, Biour M, Levy VG 1992. Acute hepatitis caused by wild germander. Hepatotoxicity of herbal remedies. Two cases. Gastroenterol Clin Biol 16: 92-95.

Pittler MH, Ernst E 2000. Efficacy of kava extract for treating anxiety: systematic review and meta-analysis. J Clin Psychopharmacol 20: 84-89.

Pittler MH, Ernst E 2003. Kava extract for treating anxiety. Cochrane Database Syst Rev 1: CD003383.

Russmann S, Lauterburg BH, Helbling A 2001. Kava hepatotoxicity. Ann Intern Med 135: 68-69.

Russmann S, Barguil Y, Cabalion P, Kritsanida M, Duhet D, Lauterburg B 2003. Hepatic injury due to traditional aqueous extracts of kava root in New Caledonia. Eur J Gastroenterol Hepatol 15: 1033-1036.

Schmidt M 2006. Is kava really hepatotoxic? Accessed: June 29, 2006, at http://www.taxtyranny.ca/images/ HTML/KavaKava/Articles/KavaReview.pdf.

Sibon I, Rosier E, Orgogozo JM 2002. Meningismus after taking kava-kava. Rev Neurol 158: 1205-1296.

Singh YN, Devkota AK 2003. Aqueous kava extracts do not affect liver function tests in rats. Planta Med 69: 496-499.

Siméoni P, Lebot V 2002. Identification of factors determining kava lactone content and chemotype in kava (Piper methysticum Forst. f.). Biochem Syst Ecol 30: 413- 
424.

Spinella M 2001. Herbal medicines and epilepsy: The potential for benefit and adverse effects. Epilepsy Behav 2: 524-532.

Stevinson C, Alyson H, Ernst E 2002. A Systematic review of the safety of kava extract in the treatment of anxiety. Drug Safety 25: 251-261.

Stickel F, Baumüller HM, Seitz K, Vasilakis D, Seitz G, Seitz HK, Schuppan D 2003. Hepatitis induced by Kava (Piper methysticum rhizoma). J Hepatol 39: 62-67.

Stickel F, Patsenker E, Schuppan D 2005. Herbal hepatotoxicity. J Hepatol 43: 901-910.

Teschke R, Gaus W, Loew D 2003. Kava extracts: Safety and risks including rare hepatotoxicity. Phytomedicine 10: 440-446.

Wheatley D 2005. Medicinal plants for insomnia: a review of their pharmacology, efficacy and tolerability. $J$ Psychopharmacol 4: 414-421.

Whitton PA, Lau A, Salisbury A, Whitehouse JS, Evans CS 2003. Kava lactones and the kava-kava controversy. Phytochemistry 64: 673-679.

Wilkinson GR 2005. Drug metabolism and variability among patients in drug response. $N$ Engl J Med 352: 22112221.

Yamada M, Kohno T, Asakawa Y 2003. Isolation and synthesis of TNF-alpha release inhibitors from Fijian kawa (Piper methysticum). Phytomedicine 10: 309-317. 